\title{
Trade-offs Between State Organisations and
} Workers' Organisations

Chinese Unions in Search of Authoritarian Collective Bargaining

\section{Chloé Froissart, Liu Yan and Meng Quan}

Translator. Elizabeth Guill.

\section{OpenEdition}

\section{Journals}

Electronic version

URL: http://journals.openedition.org/chinaperspectives/9063

DOI: $10.4000 /$ chinaperspectives.9063

ISSN: 1996-4617

\section{Publisher}

Centre d'étude français sur la Chine contemporaine

Printed version

Date of publication: 8 June 2019

Number of pages: $29-38$

ISSN: 2070-3449

\section{Electronic reference}

Chloé Froissart, Liu Yan and Meng Quan, «Trade-offs Between State Organisations and Workers' Organisations », China Perspectives [Online], 2019-2 | 2019, Online since 10 June 2020, connection on 23 December 2020. URL : http://journals.openedition.org/chinaperspectives/9063 ; DOI : https:// doi.org/10.4000/chinaperspectives.9063 


\title{
Trade-offs Between State
}

\section{Organisations and Workers'}

\section{Organisations}

\author{
Chinese Unions in Search of Authoritarian Collective Bargaining
}

\author{
CHLOÉ FROISSART, YAN LIU, AND QUAN MENG
}

\begin{abstract}
This article analyses the way in which, since 2010, Chinese trade unions have been trying to find forms of authoritarian collective bargaining that allow them to advance workers' interests without calling into question their belonging to the state apparatus. It compares the case of the Dalian Industrial Zone to that of the Shenzhen Pilot Zone in a bid to understand how the unions try to acquire effectiveness and legitimacy in the absence of any progress in terms of representation.
\end{abstract}

KEYWORDS: Trade union reforms, collective bargaining, labour disputes, strikes, labour NG0s.

A pillar of the Maoist regime, the ACFTU (the All-China Federation of Trade Unions - Zhongguo zonggonghui 中国总工会) still has the monopoly on Chinese workers' and employees' representation, at least in theory. As a mass organisation, the ACFTU has a duty to represent, at one and the same time, the interests of workers and employees, employers, the Party, and the nation as whole. More than 30 years after the re-introduction of the market economy, this founding ideological principle is at odds with the diversification of socio-economic interests, resulting in an increase in labour disputes and the appearance of alternative forms of organisation and representation such as NGOs and workers' rights lawyers (Froissart 2014a, 2014b: 12-5). The ACFTU suffers from an identity problem linked to its contradictory dual nature as both a Party-state and a workers' organisation (Chen 2003). Three problems have resulted from this, whose critical nature was highlighted by the countrywide strike wave of 2010: a problem of representation, a problem of effectiveness, and consequently, a lack of legitimacy.

In response to the growing number of labour disputes and changing demands, the early 2010s were marked by a turning point in union reform in order to take account of the growing divergence of interests between employers and employees. This article will study the ways in which Chinese trade unions search for forms of authoritarian collective bargaining that would allow them to defend the rights and interests of workers without questioning their place in the state apparatus.

To what extent do the unions succeed in this aim? The reforms are characterised by their great diversity, not only from a geographical point of view, since they are decentralised, but also from a diachronic point of view, since there have been periods of greater or lesser openness to collaboration with civil society (Howell and Pringle 2018). But over and above the various experiments, the challenge of any enterprise union reform is to find a balance between two types of effectiveness (representing the interests of union members and assisting company managers effectively whilst at the same time meeting the requirements of the union hierarchy) and two sources of legitimacy (internal legitimacy from the recognition and support of their members and external legitimacy from the inclusion of the unions in the institutional system of the People's Republic of China together with their recognition and acceptance by employers) (Wu and Wang 2017).

One way to resolve this equation would have been for the unions to integrate the voice of the workers more fully and move towards a form of social corporatism, as Anita Chan predicted at the beginning of the 1990s (Chan 1993; Unger and Chan 1995). Nonetheless, apart from a few isolated examples in the automobile (Yang 2018) and ports sectors (Pringle and Meng 2018) in Guangdong Province, most studies point to the increasing integration of the ACFTU into the state apparatus (Friedman 2014; Chan and Hui 2012, 2014). We confirm this thesis by demonstrating that enterprise unions can only increase their effectiveness through better coordination with the higher levels of the ACFTU, but also emphasise the ways in which they are attempting to rebuild their relationship with the workers in a context where the parenthesis of collaboration with civil society and the union election experiment has been closed.

A first historical section reviews the institutional and ideological foundations of the Chinese unions, the ways in which they have tried to adapt to the challenges of the market economy, and the limitations of these adaptations as demonstrated by the massive strike wave of 2010 .

The second section attempts to assess the capacity of the unions to implement "collective bargaining" underpinned by a move from self-proclaimed representation (Friedman 2014) towards a more democratic form of representation.

The third section is devoted to an analysis of the case of the Dalian Industrial Zone in Liaoning Province. An example of the successful institu- 
tionalisation of negotiations conducted by the Party-state, the reform introduced in the Zone nonetheless failed to find a satisfactory balance between contradictory imperatives and consequently did not represent a lasting solution to the problems of lack of union legitimacy and labour disputes.

The case of the Shenzhen Pilot Zone analysed in the fourth section testifies, on the other hand, to an attempt to acquire legitimacy based on the grassroots unions' wish to mobilise the workers. The Shenzhen experiment, however, reveals the limitations of reforms initiated by grassroots unions and the impossibility for them to free themselves sufficiently from the union hierarchy to become real worker organisations.

\section{The unions: Intermediary organisations between the Party and the workers that deny the existence of conflicts of interest between employers and employees}

\section{Institutional context and ideological foundations}

The ACFTU, the only permitted trade union in the People's Republic of China, of which it is one of the pillars, is organised along corporatist lines. Entirely subjected to the Party, it is the body to which all union branches are subordinate. The latter are structured as a geographical hierarchy county (xian 县), district (qu 区), municipality, province, and national level - and by sector (industrial branch). In accordance with the principle of democratic centralism whereby the Party's leadership role is justified by the fact that it embodies the national interest and reconciles the specific interests of each sector of society, the unions are responsible to the higher levels of their hierarchy and not to the employees and workers. Where under the Maoist regime companies were theoretically owned by the people, and workers were the "masters," under this system, employers and employees are supposed to have the same corporatist interests. Hence, the ACFTU was above all intended as an intermediary organisation between the Party and the people and not between employers and workers. According to the Leninist transmission belt model, the unions have two missions: top-down transmission that involves mobilising workers and employees to increase production in the name of the general interest of the nation, and bottomup transmission designed to protect the rights and interests of the workers by conveying their grievances to the Party.

The contradiction inherent in this dualism, characteristic of unions in communist regimes (Chan 2008), explains why the role of the unions has always been first and foremost a managerial role, supervising the production process and ensuring discipline in the workplace, whilst protection of employees' rights and interests has at best been interpreted as monitoring the company's managerial practice, ensuring that it complies with the laws and regulations in force and with the implementation of social services for workers (Clarke et al. 2004).

Up until now, the unions have maintained their "double institutional identity" (Chen 2003), trying at the same time to play the role of Party apparatus and workers' organisation. Whether from an organisational or a legal point of view, nothing could be further from the idea that Chinese unions have of their role than that of representing and defending the rights and interests of workers against the employers. As for their structure, the higherlevel unions are an integral part of the state apparatus, since their cadres are officials recruited through civil service exams, whilst at the grassroots level, the union is generally an integral part of the factory management, since most union leaders are company managers (Ding et al. 2001; Clarke et al. 2004). From a legal point of view, since the right to strike is not recognised, (1) unions must prevent work stoppages and in any case encourage the resumption of production (Trade-Unions Law art. 27).

\section{First attempts at adapting to the market economy: $A$ persistent denial of the existence of conflicts of interest}

Revised in 2001, the Trade Union Law of the PRC states that the core task of unions is still economic development, but it also insists that "the basic duties and functions of the unions are to protect the legitimate rights and interests of the workers and staff members" (art. 6). The Law therefore continues to maintain that a bureaucratic reconciliation of divergent interests is possible, even though the economic competition involved in entering the market economy implies that employers favour productivity and profitability over the wages and rights of employees.

Since the role of the unions as labour organisations had been severely eroded by economic reforms, the ACFTU introduced several measures both on an organisational and practical level to reinforce the identity of the unions as organisations for the defence of worker and employee rights. To compensate for decreasing membership linked to privatisations, it developed a policy of extending the unions to cover new business sectors, new types of companies, and employees such as migrant workers, although most remained "paper unions" (Taylor and Li 2007).

The unions' adaptation to the market economy went hand-in-hand with the development of labour laws, in particular with the coming into force in 2008 of the Labour Contract Law that formalised relationships between employees and employers and promoted job security, and the 2011 Social Security Law that integrated migrant workers from rural areas into the urban insurance system. The unions conducted training campaigns on the labour laws that contributed to raising workers' awareness of the law and of their rights. However, it was left to the workers to settle their differences via mediation and arbitration institutions and the tribunals, which favoured an individualised, legal approach to conflict resolution, although their cost in money and time, as well as their lack of effectiveness, discouraged most workers from using them (Gallagher 2017).

Against a background of broadening demands, frustration over the incapacity of institutional mechanisms to either implement the law or resolve conflicts beyond the required legal minimum led to a considerable increase in the number of strikes at the end of the 2000s (China Labour Bulletin 2012; Kuruvilla and Zhang 2016; Lee et al. 2016). The unions attempted to respond by favouring social dialogue rather than repression and by intervening informally between employers and employees as mediators alongside the local authorities (Chen 2010; Gallagher 2014). However, since the unions were expected to take account of the interests of employees, employers, and the local authorities as well, these negotiated solutions did not generally allow for the application of even the legal minima (Chen 2010). Finally, and in accordance with the 2008 Labour Contract Law, the unions

1. Enshrined in the 1975 and 1978 Constitutions, the "right to strike" was abolished in the 1982 Constitution, which is still in force. China has only ratified four of the eight basic conventions of the ILO, and these do not include the right to strike and freedom of association. Striking is not, however, formally against the law in China, which in practice allows for more flexible management of strikes by the authorities. 
actively promoted the signature of collective contracts in companies. However, top-down introduced collective contracts followed a bureaucratic process during which working conditions were not negotiated between employers and employees. The subordination of the factory union to the priorities of the management did not favour the development of a genuine system of collective negotiation. In general, therefore, collective contracts remained largely formal (Chen 2007; Clarke et al. 2004; Lee et al. 2016).

Tripartite consultations (from which the workers were absent, since they only involved the unions, the local authorities, and the employers) on wages were also set up at sector level, the best-known example being that of the Wuhan catering sector in 2011. However, these consultations usually resulted in purely formal agreements that were either not applied at all or only scantily, with workers for the most part unaware of their existence (Kuruvilla and Zhang 2016). The process was therefore characterised by a lack of participation on the part of employees and by the structural inability of the unions to represent them.

The reforms introduced in the 2000s still did not acknowledge the conflicts of interest between employers and employees. This denial, however, became unbearable in the light of the intensification of market reforms within a context where employers sought to maximise their profits and ensure the profitability of their companies by closing or selling factories, not paying wages or social security benefits placing the health and safety of workers at risk, dismissing workers, increasing their workload, or extending working hours (Clarke et al. 2004). It explains the chronic deficit of legitimacy from which the unions suffered, since the workers did not trust them to represent their interests. In many companies where the ACFTU was present, the employees did not even know they were represented. The unions were perceived as apathetic or on the side of the employer, which is why workers saw wildcat strikes and other forms of protest as more effective ways of resolving their grievances (Taylor and Li 2007; Howell 2008; Friedman 2014). In other words, the strikes should be interpreted as an indicator of the unions' lack of legitimacy (Chen 2010), and in 2010 this became explicit.

\section{The 2010 turning point or the triple union crisis}

2010 was a turning point. Several major disputes, triggered by the Honda Nanhai strike and given extensive media coverage, broke out in southern China before spreading to other regions in the country. This wave of strikes represented a quantitative and qualitative leap in collective, worker-led action (Froissart 2011, 2013). There was a significant increase in the number of strikers and in the frequency and length of the strikes.

From a qualitative standpoint, two major turning points characterised these strikes. Aimed at increasing wages, they symbolised a shift from disputes concerning the defence of rights to conflicts concerning workers' interests, that is to say, the redistribution of wealth in a capitalist economy (Chang and Brown 2013). Moreover, demands became more radical and political, directly tackling issues of workers' representation and the recognition of the right to strike. Workers at Honda Nanhai demanded the resignation of the union chair and the election of another. They also demanded that workers who had been on strike should not be fired. Similar demands were made in other factories in the automobile and electronics sectors in the Pearl River Delta and in companies in northern China, notably in Tianjin, Beijing, and Dalian (Froissart 2011; Chan and Hui 2012, 2014).
Demonstrating the degree of dissatisfaction concerning working conditions and testifying to progress in the ability of workers to voice collective demands and organise themselves autonomously (Chang and Brown 2013; Froissart 2013), this wave of strikes highlighted the triple crisis of the unions: representation, effectiveness, and legitimacy. The disputes constituted a peak in "collective bargaining by riot," to use Hobsbawm's phrase (Chan and Hui 2014), and most were settled through negotiations between temporarily elected workers' representatives and employers thanks to the mediation of local governments and unions (Meng 2012; Chan and Hui 2014). The desire to prevent such disputes from recurring led to the creation of new types of annual wage negotiations, which will be studied below.

At the same time, following a growing awareness of rights linked to changes in legislation, the unions also had to deal with new claims based on the law such as demands regarding working hours, safety in the workplace, and above all social security benefits, including retirement and contributions to the housing benefit fund (Gallagher 2017). Highlighted by the emblematic and large-scale dispute at the Yue Yuen shoe factory in 2014, demands were also made when smaller factories closed or were relocated, as has happened with increasing frequency in Guangdong in recent years following increases in labour costs and the will of the provincial authorities to start an economic transition to sectors of higher added value. Illustrating also the marginalisation of the unions, the workers have generally been supported in these disputes by NGOs, who have trained them to conduct collective bargaining autonomously (Froissart 2014, 2018). Seen as direct competition to the unions, the development of these labour NGOs has also been a spur to the reform of the unions in Guangdong, as the final section of this article will show.

\section{The implementation of collective bargaining: A small step towards representation}

Since the 2010 wave of strikes, the purely formal consultation system "based on the continuing assumption of a community of interests between the enterprise and the workers expressed in a common commitment to the observance of legal norms" (Clarke et al. 2004: 237) has significantly evolved towards a plurality of bargaining systems whose aim is "to obtain for the workers a larger share of their employers' profits than would otherwise be the case" (Lee et al. 2016: 232). However, few of these negotiations are based on a reform of union representation.

In Guangdong, the 2010 strikes renewed the impetus for the implementation of union elections in factories, which had already been held from time to time in the mid-1990s, notably in the provinces of Zhejiang, Shandong, and Guangdong. These elections were never institutionalised or systematised at a national level, notably due to a lack of political support (Howell 2008), and moreover did not alter the operating modes of unions, since union leaders remained subordinate to factory managers (Pringle 2011). The particularity of the wave of factory union elections organised between 2010-2013 was that it responded to pressure from the workers and benefitted from strong union support at both the national and local level. It was then admitted that the unions' lack of representativeness and their dependence on the factory management was the key to their lack of power. The idea of "direct" and "democratic" elections of union leaders that would lead to the "professionalisation of the unions" was strongly supported by the Party secretary of Guangdong Province, the vice-president of the Provincial Union Federation, and the vice-president of the Shenzhen Union 
Federation, who announced that direct elections would be held in 163 companies following the strike at Omron Electronics in March 2012, the main demand of which was the election of a new union (Froissart 2015; Hui and Chan 2015).

To our knowledge, no overall assessment of these elections exists, and the exact number of elections effectively organised remains unknown. It would seem, however, that these initiatives gave rise to two types of elections and negotiations: manipulated elections resulting in occasional negotiations led by the Party-state (Chan and Hui 2012, 2014) that did not represent significant progress in union reform, and relatively fair elections that enabled the institutionalisation of annual wage negotiations led by workers' representatives alongside the union management, and testified to a move towards societal corporatism in some companies.

In big companies such as Honda and Omron, which served as models, these elections did not fulfil their promises (Froissart 2015; Chan and Hui 2014; Hui and Chan 2015). As with previous experiments, the elections, which remained indirect, were strictly supervised by the union hierarchy and often manipulated by the employer, since candidates were filtered and activists systematically rejected, whilst the union chairs often remained subordinate to the factory management. In these companies, therefore, the elections did not fundamentally change the identity or the operational methods of the factory unions and were sometimes even followed by new strikes for wage increases and for the election of a new union chair (Hui and Chan 2015).

The high media coverage of the collective bargaining at Honda Nanhai in February 2011, which resulted in substantial wage increases one year after the strike, owed its success to the ad hoc intervention of the vice-president of the Guangdong Province Union Federation within a context where it was important for both Honda and the unions to redeem their tarnished image, rather than to an increase in the workers' institutional power (Froissart 2013; Chan and Hui 2012, 2014). Since the cost of this type of ad hoc intervention was very high, and since provincial union representatives could not physically travel to supervise wage negotiations in all of the province's companies, the "model" did not become systematic and remained an isolated case.

Nonetheless, other studies highlight more positive results. Based on his observations on the case of two Japanese companies in the automobile industry in Guangzhou, Yang (2018) describes what he calls an "endogenous" electoral model characterised by a high level of involvement on the part of the workers and minimal intervention on the part of the union hierarchy, limited to introducing the legislation in force and supported by the employers, who feared large-scale conflict and did not seek to manipulate them. These direct, semi-competitive elections (with more candidates than posts) resulted in an employee becoming union president in one of the companies. These elections were followed by annual negotiations that led to wage increases. Lee, Brown, and Wen (2016) also describe a form of hybrid representation in three electronics companies (Japanese multinationals) consisting of an annual election of worker representatives who take part in wage negotiations alongside union officials. Their participation in the negotiations resulted in greater accountability to employees' demands, in particular concerning long-service bonuses and the reduction of wage differentials.

The available studies therefore illustrate strong variations from one company to another and are too fragmentary to enable a comprehensive appraisal. Together they support the thesis of greater integration of grassroots unions into the Party-state apparatus and greater organisational autonomy for grassroots unions and their members. It would seem, however, that if these elections provided an overall, long-lasting solution to the problem of the absence of union legitimacy and the concomitant problem of the subordination of unions to the factory management, strikes would have become less frequent in Guangdong, but this is not the case. (2) Limited to a few companies in Guangdong in fast-expanding sectors and with a high concentration of capital, these elections do not seem destined to develop on a wider scale. On the one hand, the replacement of the Party secretary of Guangdong in 2013 symbolised a conservative turnabout that interrupted democratic experiments at the enterprise level, while a report published in 2017 by the ACFTU's leading group on union reform pilot zones mentions the elections and companylevel negotiations only in passing. (3)

Lastly, there are a few rare examples of effective sector-based negotiations, ${ }^{(4)}$ in which employers, who form an association, have a direct interest in promoting these negotiations in order to fight against strikes and a lack of manpower and job instability or to limit competition between companies in the same sector. Although sector-based negotiations are not underpinned by union elections, they can, on occasion, be opened up to worker participation. Lee, Brown, and Wen (2016) describe negotiations involving village and township enterprises in two cities in Jiangsu that have introduced a "limited and controlled participation" of workers and employees, previously selected from the sector's union association where employers also sit. These negotiations not only facilitate wage increases but also the improvement of working conditions (seniority allowance, promotions, training). This new system of hybrid representation at the sector level - without recourse to an election - is the most successful case of union reform with regard to the implementation of collective bargaining, but does not seem to have been reproduced elsewhere.

\section{Negotiation in favour of workers without democratic legitimacy? Dalian: An institutionalised model of negotiations led by the Party-state}

The model of Dalian Jinzhou New District (DJND) in Liaoning Province is an interesting example of institutionalised negotiations conducted by the Party-state that combine the regional, sectorial, and enterprise levels, and which whilst seeking to build a link between company unions and the employees also considerably reinforce the power of the factory unions and convincingly remedy their subordination to company management.

The DJND, established by the State Council in 1984, ${ }^{(5)}$ was the first national economic and technological development zone. In 2015, it had 3,500 factories and foreign-capital companies, including investments by 75 com-

2. The map of strikes published by China Labour Bulletin invariably shows Guangdong as the region with the most strikes: http://maps.clb.org.hk/strikes/in\# (accessed on 2 June 2018).

3. 全国总工会改革试点工作领导小组 (Quanguo zonggonghui gaige shidian gongzuo lingdao xiaozu, Leading ACFTU group on the pilot zones for union reforms), “关于全国总工会改革试点 工作的总结报告" (Guanyu quanguo zonggonghui gaige shidian de zongjie baogao, Summary report on pilot work on the reform of the National Federation of Unions), 28 March 2017, http://cmqfyc.acftu.org/art/2017/3/28/art_378_245605.html (accessed on 2 January 2019).

4. The best-known example is that of Wenling in the knitwear sector, established in 2003, renegotiated since and effectively applied (Wen and Lin 2015). This model does not, however, allow for workers' participation.

5. The name of the industrial zone has changed twice since it was established. It was renamed Dalian linpu New Area in 2015. 
panies listed in the Fortune 500. (6) The zone has a tradition of activism. In 2005 , it experienced a wave of strikes involving more than 20,000 workers over wage increases. The resolution of strikes displayed a four-party mechanism characterised by informal participation on the part of the workers and the establishment of the zone's union as mediator between employees, employers, and the government, introducing for the first time representation of the company's unions by the union hierarchy (Chen 2010).

However, according to Chen, this mechanism represented a low level of institutionalisation of industrial relations, given that the employers were not organised into associations, and the zone's union had to negotiate the same demands with each company affected by the strikes. From the end of May to the end of August 2010, echoing the Honda Nanhai strike, the DJND experienced the biggest wave of strikes in its history, which spread to 73 companies (46 of which were Japanese) involving more than 70,000 people. As in the case of Honda Nanhai, the local unions in Dalian helped the striking factory workers negotiate an average wage increase of $34 \%$. ${ }^{(7)}$ In order to swiftly end the conflicts, the company unions asked workers to elect representatives, helped the latter to collate the workers' demands, and persuaded employers to negotiate with the union chair and the workers' representatives to agree on the amount of wage increases. In certain cases, the industrial zone's union lent its support to the factory unions in the negotiations. All the disputes were settled thanks to collective bargaining over wages (Meng 2012).

This experience of massive strikes and the way in which they were settled served as a guide to the reforms implemented in 2011, the aim of which was to rebuild the wages consultation system, which, as is often the case in China, excluded employees and consisted of the unions approving the decisions of the factory management. It aimed to take the concerns of the workers into account and at the same time to meet the expectations of Dalian's local government, which wanted to see the unions play a more active role in the prevention and resolution of disputes.

This section is based on fieldwork carried out between 2011 and 2012 by the third author. Eight foreign-investment companies were selected as a sample. All had been affected by the 2010 strikes and had a union. This author conducted 32 semi-directed interviews with the union representatives of the industrial zone and factories, the managers of these factories, local government representatives, and employees - placed in discussion groups - who had participated in the 2010 strikes and taken part in wage consultations. A follow-up study was carried out in 2013.

The reforms, initiated by the Industrial Zone Union (gongye shequ gonghui 工业社区工会), operated on three levels. Firstly, and in conformity with the doubling of income announced by the central government during the $18^{\text {th }}$ Congress of the CCP, ${ }^{(8)}$ the Industrial Zone Union (IZU) drew up a five-year plan for progressive wage increases ${ }^{(9)}$ to serve as a reference point for the negotiation of framework agreements for the entire Zone between the IZU and the local Chamber of Commerce representing the interests of the foreign companies. Thanks to regular meetings held between the IZU and the Chamber of Commerce that also included company unions and company management representatives, the different parties gained a better understanding of their respective interests and favoured compromises. The IZU therefore ensured that wages were index-linked to the cost of living, and in doing so remedied one of the main faults of the traditional collective consultation mechanism, ${ }^{(10)}$ whilst the local Chamber of Commerce obtained a guarantee that increases would remain compatible with the profitability of the companies, who consequently proved more inclined to accept them.
The framework agreements were then sent to the companies, and the grassroots unions were tasked with negotiating actual wage increases with their factory management. ${ }^{(11)}$

The second innovation was the re-institutionalisation of the Staff and Workers Representative Congresses (zhigong dabiao dahui 职工代表大会), with an emphasis on their role in wage consultations. Created in the Maoist era to enable state-owned companies to improve their productivity thanks to the participation of workers and employees, and extended to all types of company in 1981, ${ }^{(12)}$ these congresses were not supposed to oppose the factory management but rather were to work in deliberation with them in order to further the interests of the company (Clarke et al. 2004; Zhu et al. 2005). The congresses are subordinate to the factory union, which represents its executive body, and are responsible for organising the election of representatives, supervising the company management, and representing the interests of the workforce in between congress meetings (Ding et al. 2001). Reinvigorated in companies in Dalian during the 2010 strikes, the Staff and Workers Representative Congresses (SWRC) played an important role in their resolution, since they allowed strikers to choose representatives to participate in the negotiations and approved the results of the latter.

The Dalian experiment did not fundamentally modify the traditional composition and function of these congresses (Zhu and Chan 2005). Essentially, they are still made up of production line managers, white-collar workers, and a few long-service "loyal manual workers," most of whom are already union members. These representatives are chosen by the body of the workers of each workshop with the approval of union managers. Managers may take part in the council in order to represent corporate interests. But a new role has been assigned to them during wage consultations. The union presents a wage raise proposal that is sometimes debatable but has always been approved by the workers' representatives. ${ }^{(13)} \mathrm{A}$ preliminary agreement, the point of which is above all to obtain the agreement of the workers' representatives, is established between these representatives and the union before it formally presents the wage raise proposal to the management. The SWRCs are therefore mainly mobilised by the unions to gain additional legitimacy in their negotiations with the factory management, in which the workers' representatives do not take part. (14) In fact, the unions see fuller

6. Yan Hui 严惠, “3500 家企业进驻金普新区” (3500 jia qiye jinzhu Jinpu xinqu, 3,500 foreign companies in the new district of Jinpu), Daliao Web, 12 September 2015, http://n.qq.com/ a/20150912/008316_1.htm (accessed on 4 June 2018).

7. "Dalian stoppage wave: Involving 73 enterprises and 70,000 workers, settled with a $34.5 \%$ wage increase," Caixin Online, 19 September 2010, http://www.wyzxwk.com/Article/shidai /2010/12/175141.html (accessed on 4 June 2018).

8. “众说十八大 '收入倍增” 计划” (Zhongshuo shibada "shouru beizeng jihua," The public discusses the $18^{\text {th }}$ Congress's "double income plan"), 法制日报 Fazhi Ribao, 20 November 2012, http://politics.people.com.cn/n/2012/1120/c1026-19634522.html (accessed on 2 June 2018).

9. “田青叶: 紧紧抓住集体谈判的“牛鼻子': 专访大连金州新区总工会主席田青叶” (Tian Qingye: jinjin zhuazhu jiti xieshang de "niubizi": zhuanfang Dalian Jinzhou xinqu zonggonghui zhuxi Tian Qingye, Taking collective consultations by the horns: An interview with Tian Qingye, President of the Federation of Unions of the new Jinzhou district in Dalian), 中国工人 Zhongguo Gongren 2013(3): 9.

10. Interview with the vice-president of the IZU, 30 July 2011.

11. Negotiations can also take place with the national chambers of commerce, notably to cope with the frequency of disputes in Japanese companies.

12. According to official statistics, $52.8 \%$ of companies with a union had a Staff and Workers Representative Congress in 2011 (Lee et al. 2016: 221)

13. On the contrary, during the 2010 strikes, the workers' representatives were charged with assembling the staff and workers' pay rise demands. These were then discussed within the congress between the representatives and the union in order to obtain a compromise likely to satisfy all parties.

14. Zhu and Chan (2005) also demonstrated that in certain circumstances, the SWRCs could be used by the company unions to reinforce their status. 
integration of staff and workers' congresses and collective consultations on wages as a means of counterbalancing their lack of democratic legitimacy. ${ }^{(15)}$ The workers' representatives are therefore used by the factory union to attempt to bridge the gap with the rank-and-file workers: the union tells them what it does to defend the interests of workers and employees and the concessions made by the management, and it is up to the representatives to transmit this information to the workers in order to win their support. As a union official says:

Why is the SWRC such a good thing? For example, we needed 160 signatures to support a wage proposal, and we would never have obtained them without the workers' congress, which enabled us to bring together many workers' representatives, whom we asked to sign after explaining to them the aim of the proposal. The congress also helped us agree on a wage rise proposal with the representatives before talking to the management. It's much better than stoppages and demonstrations! So the management also appreciate this method. ${ }^{(16)}$

This was confirmed by the director of a Japanese company:

We think it is a positive gesture on the part of our company's union to discuss questions of wages during SWRC meetings. It means the staff understands our position better. ${ }^{(17)}$

The SWRC therefore allow company unions to reinforce their role as mediator between employers and employees. On the one hand, the union, feeling more supported by the workers, is in a better position to negotiate wage rises and can warn the employer that it will have difficulty preventing stoppages if he is not open to negotiation. On the other hand, the union can temper workers' expectations by explaining the constraints the employer is facing, and by encouraging them to realise the effectiveness of negotiations and in which ways they are more advantageous than strikes.

The third DJND innovation that reinforced the bargaining power of the factory unions was the creation of an association of foreign-investment company unions (AFICU) that allowed the IZU to lend its support to the factory unions. Together with the union hierarchy and the Party committees in major companies, the IZU coordinated their work whilst helping inexperienced union officials to involve themselves fully in negotiations with employers. The Association also introduced a sector-based dimension into the negotiations that allowed unions to coordinate their actions, thereby rendering the Association more effective and uniform. The grassroots unions met regularly within the nine branches of the Association and obtained information that enabled them to move forward negotiations in companies in the same sector. As a union chair says:

Exchanging information enabled us to act (...). If an employer refused our proposal, we could always say that other companies had already agreed to a similar wage increase. ${ }^{(18)}$

The Association therefore enabled the factory unions to escape their isolation in the face of employers and counterbalance their structural subordination to them thanks to sectoral coordination and increased controls by the IZU over negotiations in factories.

Held every year since 2011 after the Chinese New Year, these negotiations enabled regular wage increases in the DJND (on average 17\% in 2011,
$13.5 \%$ in 2012, and $10.3 \%$ in 2013). ${ }^{(19)}$ Compared to the four-party model (Chen 2010), these reforms represent the institutionalisation of negotiations thanks to the organisation of employers in the Chamber of Commerce and the institutionalisation of coordination between different levels of the AFICU union. Whilst they remain within the framework of "negotiations led by the Party-state," these reforms sow the seeds of social dialogue that allows workers to be better informed of the procedures and content of negotiations. They free grassroots unions from the tutelage of the factory managers, allowing them to take on the role of negotiators in their own right, and to be more effective in the promotion of the workers' interests.

However, unlike the jiangsu model mentioned above, these negotiations did not establish worker participation. Neither the representatives, and even less so the rank-and-file workers, take part in drawing up proposals and in negotiations. Although this new system promotes the bargaining power of the unions, it remains a consultation system. These reforms aimed to counterbalance the power struggle between the grassroots unions and the factory managements. While they were presented as a model of "democratic management" (20) (minzhu guanli 民主管理), they correspond in fact more to a reinforcement of the control of the union hierarchy over the grassroots unions than to progress in democratic reform, since the participation of the representatives is intended to solicit the support of the workers for the proposals of the unions with a view to preventing disputes, and not to promoting debate and even less the participation of the workers in the decision-making process. Lastly, during negotiations, the union plays a role - that has now become established - of mediator between employer and employees and not, strictly speaking, of workers' representative. This explains why, despite the constant wage increases in the Industrial Zone since the implementation of the reforms, a few workers continue to show their discontent with their working conditions, with the way in which the workers' congresses operate, and display a low level of confidence in the unions. As one worker said:

Ultimately, I think the union officials follow the instructions of the management because they are paid by the company. I don't think the union dares oppose the management where wages are concerned. (21)

In other words, these reforms have not significantly solved the lack of union legitimacy. Moreover, the negotiations only concern wages, and strikes over other failures to comply with labour laws, notably the absence of social security and abusive dismissals, broke out in Dalian in 2012 and 2014, one of which, at Dalian Konica, involved more than 1,000 workers. (22) Since the workers do not feel truly represented, these reforms have not per-

15. Informal interview with a high-ranking union official in the Industrial Zone, 17 August 2011.

16. Interview with a union official, DJND, 17 August 2011

17. Interview with the director of a Japanese company, DJND, 18 August 2011

18. Interview with a union president, DJND, 1 August 2011

19. Suo Cheng 索成, “集体协商: 我的工资我做主” (Jiti xieshang: wo de gongzi wo zuozhu, Collective consultations: I can determine my wage), 当代工人 Dangdai Gongren, 2015(4): 21.

20. Wang Lei 王雷, “大连金州新区总推进集体协商工作, 维护职工劳动经济权益” (Dalian Jinzhou xinqu zong tuijin jiti xieshang gongzuo, weihu zhigong laodong jingji quanyi, The Federation of Unions of the DJND promotes collective consultations to protect the rights and economic interests of the workers), WorkerCN, 5 November 2014, http://right.workercn.cn/900/201411/05 /141105135637237.shtml (accessed on 6 June 2018).

21. Interview with a worker in a Japanese company, 18 July 2011.

22. See the China Labour Bulletin's interactive map of strikes: http://maps.clb.org.hk/strikes /in\#201401/201412/1587 (accessed on 2 June 2018). 
manently contained the strikes nor resulted in any demonstrable increase in confidence in the unions.

The example of Dalian shows, however, that the unions can, to a degree, be effective in the long-term without progress in terms of representation. In other words, effectiveness and legitimacy can be dissociated to a certain extent. In effect, as the case of Jiangsu shows, only progress in worker representation and participation enables the demands of the employees to be considered in all their diversity.

The next case study shows a reverse strategy in which the reform places the emphasis on drawing closer to the workers and the acquisition of legitimacy by the grassroots unions. Despite the wish of the unions to "become more democratic and closer to the masses" (23) and the desire of young grassroots union officials to become more autonomous in order to help the workers organise themselves in face of their employers, the example of the Shenzhen Pilot Zone illustrates, on the contrary, a lack of effectiveness in the defence of workers' interests.

\section{Drawing inspiration from labour NGOs in conducting collective bargaining: The example of Shenzhen}

From 2011 to 2015, the unions and local governments of Guangdong Province tolerated forms of ad hoc cooperation with labour NGOs and lawyers (Froissart 2014b, 2018) as a way of integrating workers' voices more fully into the state bureaucratic system without changing the nature of the unions. Unions and labour bureaux acted as the guarantors of true collective bargaining between employers and autonomously organised workers thanks to the support of the NGOs and lawyers. ${ }^{24)}$ These negotiations, initiated and led by democratically elected workers' representatives, rebalanced power relations within the company and could result in the application of legal measures relating to a widely varied range of demands (payment of social security contributions and to the housing aid fund, relocation and factory closure indemnities, paid holidays, etc.) as well as benefits not stipulated in law (wage increases, severance payment, etc.).

Since these negotiations promoting the workers' movement represented a danger in the eyes of those in power, the NGOs supporting them were seen as direct competitors to the official unions and were severely repressed in December 2015. In the same year, the coming into force in Guangdong Province of the Regulations on Collective Contracts restored the monopoly of the ACFTU on the management of labour disputes (Froissart 2018). The grassroots unions in Shenzhen nonetheless tried to learn from the experience of the NGOs to reform and rebuild their ties with the workers.

Observing that "in the future, contradictions between labour and capital will not only remain at a high level but will also become increasingly acute," a report by the Shenzhen Federation of Unions (SFU) called for innovations in union reforms, creating an "avant-garde organisation" capable of "managing disputes between employers and employees at source." (25) A Pilot Zone (shiyanqu 试验区) was thus established in the Autumn of 2014 in two of Shenzhen's industrial districts. Its mission was to "create a model of corporate democracy centred on union activists and worker elites mainly focused on the establishment of unions, the setting up of democratic elections, and collective consultations" in order to "prevent major labour disputes and participate in settling them." (26)

Echoing the words of Xi Jinping in October 2013 calling for unions to "attract workers and employees to them, grow closer to the grassroots and the masses, and meet their expectations better," (27) the creation of this Pilot Zone should also be seen in the light of the development of the activities of those NGOs involved in collective bargaining, who were accused of fanning the flames of conflict. (28) The fieldwork in this section was carried out by the second author between December 2014 and May 2015 when she was employed as a trainee by the union in the Pilot Zone. It consisted of formal and informal interviews with unions at different levels, employees, employers, and the labour bureau and in participant observation sessions of the training, negotiations, and activities of the unions in $\mathrm{H}$ industrial district. A follow-up study was carried out in December 2016.

The management of the Pilot Zone was entrusted to young union officials whose recruitment contrasted with their traditional sociological profile. Neither civil servants nor company managers, they had diplomas in sociology, social work, industrial relations, or law. Some completed courses in NGOs or devoted their end-of-study thesis to them. These young union officials were therefore familiar with the work of the NGOs involved in collective bargaining, and the implicit requirement was to emulate them. All displayed real enthusiasm and a sincere wish to help the workers.

The union in the Pilot Zone offered a series of training courses and activities outside the factories. Like the NGOs, they tried to get closer to the workers by establishing themselves in the industrial district, creating social ties there such as the "workers and employees clubs" (zhigong zhijia 职工 之家) and cultural and sporting associations and offering continuing vocational, health, and general culture courses, etc. Like the NGOs, the union officials organised activities in the evening or on weekends to allow more workers to take part. They appeared to be receptive, open-minded, and ready to listen to the workers and to communicate with them via social media. Chat groups enabled them to give notice of activities organised by the unions and to collect the workers' complaints. They even went so far as to contact workers directly to take note of their needs. The aim of this charm offensive was to regain the confidence of the workers by demonstrating to them that the union was at their service. The effort at "grassroots mobilisation" (jiceng dongyuan 基层动员) was concentrated on training "activists" (iiji fenzi 积极分子), in other words, workers who support the union. Often responsible for cultural and sports associations, these activists were charged with explaining the role and purpose of the unions to the workers and employees and creating a link between workers and the Pilot

23. “深圳市总工会关于建立源头治理劳资纠纷试验区的决定” (Shenzhen shi zonggonghui guanyu jianli yuantou zhili laozi jiufen shiyan qu de jueding, Decision of the Shenzhen Union Federation concerning the creation of a pilot zone for the management at source of labour disputes), 15 September 2014. Document on file with the authors of which the following article gives a summary: 全国总工会集体合同部调研组 (Quanguo zonggonghui jiti hetongbu diaoyanzu, Research and study group on ACFTU collective contracts), “深圳建立源头治理劳资纠纷试验区" (Shenzhen jianli gonghui yuantou zhili laozi jiufen shiyanqu, Shenzhen establishes a pilot zone to manage labour disputes at source), 12 May 2015, http://media.workercn.cn/115/201505/12 /150512092829987.shtml (accessed on 4 June 2018).

24. Since the NGOs remain independent, this collaboration is different from the welfarist incorporation process analysed by Howell (2015). NGOs are not incorporated into the unions, so they do not call into question the latter's corporatist nature whilst at the same time obliging them to play their role as worker organisations better.

25. “勇于改革锐意进取在源头治理劳动关系中发挥重要作用” (Yongyu gaige ruiyi jinqu zai yuantou zhili laodong guanxi zhong fahui zhongyao zuoyong, The courage to reform, lead the way and play an important role in the governance of labour relations at their source), Report of the $11^{\text {th }}$ plenary session of the $5^{\text {th }}$ Congress of the Shenzhen Federation of Unions, 16 April 2014, http://www.szzgh.org/manage/news/detailnews.asp?id=25603 (accessed on 4 June 2018).

26. “深圳市总工会关于建立源头治理劳资纠纷试验区的决定," art. cit.

27. “习近平同中华全国总工会新一届领导班子集体谈话” (Xi Jinping tong Zhonghua quanguo zonggonghui xin yijie lingdao banzi jiti tanhua, $X i$ Jinping conducts a dialogue with the new directors of the ACFTU), Xinhua, 23 October 2013, http://www.gov.cn/ldhd/201310/23/content_2513659.htm (accessed on 4 June 2018).

28. ACFTU collective contracts Research and Study Group, art. cit. 
Zone Union (PZU). The real reason for these communication channels with the workers (activities, social networks, activists) was to allow the PZU to be the first to know about any strikes in order to intervene as quickly as possible.

The first dispute the PZU faced broke out in late November 2014 in a small Chinese electronics factory of 253 employees with no union. When they understood that the management intended to relocate following a decline in business, the workers went on strike, blocking the main entrance to the factory while demanding that the management announce a relocation plan and pay the relevant compensation.

A typical case of recourse to the institutionalised mechanisms of conflict resolution being of no use, disputes relating to relocation had to be resolved by negotiations, hitherto taken care of by the NGOs. Drawing inspiration from the method developed by the latter (Froissart 2014, 2018), the PZU trained the workers to elect representatives, established as such by a procuration signed by the employees. It helped the representatives to collect demands and to write a letter listing their demands to their employers, inviting them to take part in negotiations.

However, accelerated training organised by the subdistrict union (jiedao gonghui 街道工会) and by the labour bureau left the workers' representatives defenceless when faced with the mysteries of the negotiation process. They found themselves unable to hold their own against the labour bureau officials, who had a supervisory role and regarded their demands as unacceptable, considering them either to have no foundation in law, ${ }^{(29)}$ or, as far as social security payments, housing benefit, overtime etc., were concerned, that they should be dealt with via institutionalised dispute resolution channels. The failure of the negotiations created divisions among the strikers: the younger strikers, representing the majority of the employees, declared themselves ready to leave the company without compensation if the employer promised not to withhold wages, whereas a minority of employees with a longer record of service wanted to continue the fight to obtain compensation. Exploiting these divisions in order to hasten resolution of the dispute, the union helped most of the employees negotiate the possibility of resigning immediately without loss of wages, leaving the others to their fate.

The dispute was settled after only two days of negotiations: 38 people left the company with full wages but no compensation, 14 signed the relocation contract under the company's conditions, and the rest of the workforce received a bonus for not having gone on strike. Although certain workers understood the powerlessness of the PZU in the face of its hierarchy, the episode was not a determining feature in the restoration of union legitimacy.

The PZU is innovative in relation to the traditional methods of unions in that it tries to "get closer to the field" (jiediqi 接地气), win the confidence of the workers, and bring their demands to the notice of the management, whilst at the same time training the workers' representatives to take part in collective bargaining. This episode of negotiation nonetheless highlighted the differences in objectives and methods in the negotiations conducted respectively by the PZU and the NGOs. For the NGOs, collective bargaining represents a means of emancipation for the working classes. But the unions consider it above all a means of settling labour disputes rapidly and avoiding their spread and radicalisation, since the unions' objective is the maintenance of social stability. As a mass organisation, the unions' main task is to help the labour bureaux in their "social management" (shehui zhili 社会治 理) task by ensuring that "major mass incidents become minor and that minor incidents are resolved rapidly" in order "not to alarm the leaders" and to "limit their social influence." (30)

This was indeed what the PZU was reminded of by its supervisors, the district committee union, and the labour bureau, who closely controlled the workers' training and the negotiations. The labour bureau confined itself to its traditional institutional role of reminding those concerned of the legislative measures in force in order to ensure that the workers "defend their rights in accordance with the law" (yifa weiquan 依法维权) whilst in reality interpreting the law in favour of the employer and directing the workers towards institutionalised channels of conflict resolution, thereby totally negating the raison d'être of collective bargaining.

On the contrary, collective bargaining envisaged by the NGOs aims to remedy the deficiencies of the institutions in dealing with disputes whilst allowing the workers to defend their interests (Froissart 2014a, 2018). Considering that the purpose of the unions is not to intervene alongside the workers during strikes, the role of the union consisted of putting pressure on the PZU to resolve the dispute in accordance with the directives of the Party, and to exploit divisions among strikers in order to settle it more quickly.

Therefore the traditional methods of maintaining social stability - promoting division amongst protestors and rewarding strike-breakers - have prevailed to the detriment of NGO methods favouring the maintenance of unity and solidarity amongst the workers (Lee and Zhang 2013). A prisoner of its position within the hierarchy of state and Party, the PZU found itself without the means of changing the habitus of its hierarchy or of helping the workers put pressure on their employer. These negotiations therefore did not even ensure the enforcement of the legislation.

Despite the small scale of the experiment, higher-level unions did not consider it expedient to replicate it. Conscious of its weak position and of the hostility of the union hierarchy towards its efforts to mobilise the workers, the PZU then devoted itself mainly to recreational activities and restricted its work on the defence of workers' rights to individualised legal advice, thereby resuming its traditional functions. The PZU nonetheless developed a role in the preventive management of disputes by relying on greater coordination with the factory unions and the city government, as well as on the "activists" charged with reassuring employees and transmitting union directives to them.

Preventive action such as this was, however, only implemented in big companies with a union and where the large number of employees meant there was a risk of major conflict. Despite the unions' wish to follow the instruction to "get closer to the masses," their position in the bureaucracy of the Party-state prevents them playing the role of catalyst in the organisation of the workers and exercising real union power (Chan and Hui 2012). The example of the Shenzhen Pilot Zone illustrates the limitations of the reforms through the incapacity of the grassroots unions to free themselves from the tutelage of the Party-state and develop into real workers' organisations. Although it attests to an evolution of union practices at the grassroots level, there has been no structural innovation. On the contrary, it represents a step backwards in relation to the previous era marked by union elections and collaboration with

29. Since the legislation was not clear on this point, the Labour Bureau held that the employer was not obliged to compensate the employees before relocation of the factory had effectively taken place.

30. Interview with the PZU, industrial district $H$, Shenzhen, 2 December 2014. Report of the $11^{\text {th }}$ plenary session of the $5^{\text {th }}$ Congress (...), art. cit. 
NGOs and lawyers. Shenzhen thus confirms the theory of the reincorporation of the unions and of society into the Party-state (Howell and Pringle 2018).

\section{Conclusion}

Without giving up their dual identity, Chinese trade unions seem to have understood the necessity of adapting to the challenges posed by the introduction of the market and the growing ability of workers to organise themselves autonomously. Whilst remaining an integral part of the Party-state apparatus, the ACFTU is attempting to free itself from its role as a transmission belt in the strictest sense of the term in order to be able to better represent the interests of workers and employees. Since the countrywide wave of strikes in 2010, there has been a significant move from a purely formal consultation system towards a plurality of systems of negotiation that represent an acknowledgement of the divergence of interests between employers and employees.

Over and above the diversity of the reforms enacted at the local level that at present show no signs of either uniformization or systematisation, there exist some permanent features. The effectiveness of the unions has progressed without any significant changes in representation. The results of the elections in Guangdong, although incomplete, would not seem to indicate any major developments. In the course of negotiations, the unions represent the interests of the workers only up to a certain point and within the framework of a mediation that must also take account of the interests of employers and local governments (Chen 2010). As the successful institutionalisation of union reform in Dalian confirms, the increased effectiveness of the ACFTU is based on the relative emancipation of the grassroots unions from the corporate management in two ways: the strengthening of their integration into the Party-state apparatus, illustrated by better coordination between the different levels of the unions, and the reconstruction of the relation between grassroots unions and their members through the reactivation of the Staff and Workers Representative Congresses.

This process has enabled the subjective evolution of the unions in relation to the employers and through the limited introduction of power relationships, an understanding that collective consultations should be more than a simple bureaucratic exercise. However, to the extent that the drivers of such effectiveness remain disconnected from the evolution of representation and leave little space for any effective participation on the part of the

\section{References}

CHAN, Anita. 1993. "Revolution or Corporatism? Workers and Trade Unions in post-Mao China." The Australian Journal of Chinese Affairs 29: 31-61.

CHAN, Anita. 2008. "China's Trade Unions in Corporatist Transition." In Jonathan Unger (ed.), Associations and the Chinese State: Contested Spaces. London: ME Sharpe. 69-85.

CHAN, Chris King-chi, and Elaine Sio-leng HUI. 2012. "The Dynamics and Dilemma of Workplace Trade Union Reform in China: The Case of the Honda Workers' Strike." Journal of Industrial Relations 54(5): 653-68.

CHAN, Chris King-chi, and Elaine Sio-leng HUI. 2014. "The Development of Collective Bargaining in China: From 'Collective Bargaining by Riot' to 'Party State-led Wage Bargaining'." The China Quarterly 217(March) 221-42. workers, it had no effect on either the crisis of union legitimacy or on the steadily growing number of strikes.

As Chan and Hui (2012) noted, the support of the hierarchy, which conditions the effectiveness of company unions, also signals the limitations of the reforms, with the example of the Shenzhen Pilot Zone confirming the impossibility for grassroots unions to free themselves from the tutelage of the Party-state and develop into real workers' organisations. In response to Xi Jinping's call for unions to draw closer to the workers in order to respond more effectively to their expectations, and anxious to compete with the NGOs in promoting an autonomous model of collective bargaining, the Shenzhen Federation of Unions has cleared the way for granting grassroots unions greater latitude in organising workers.

Nonetheless, against a background of abandoning union elections and the end of collaboration with civil society, the grassroots unions have not been able to strengthen the workers' negotiating power nor counterbalance their weakness in relation to their employers and the state. If the last example confirms that reforms cannot easily be set in motion by grassroots unions, it also underlines the limitations of the innovations in Guangdong Province and the unions' return to a disciplinary role and that of service providers.

Lastly, the examples of Dalian and Shenzhen confirm the desire of the unions to increase their efforts to prevent disputes. However, this strategy is only effective at the level of an industrial zone or in large companies that are relatively standardised in terms of the labour laws and have a union, which means that workers in SMEs that are less respectful of the legislation and do not have a union branch are left to their fate. Although it may have an impact on the prevention of "major disputes," this strategy therefore remains inappropriate for significantly limiting the overall number of strikes.

\section{Translated by Elizabeth Guill.}

IChloé Froissart is associate professor in Political Science in the Department of Chinese Studies at the University of Rennes 2. She was director of the Franco-Chinese Social Sciences Centre at Tsinghua University, Beijing (chloefroissart@gmail.com).

I Liu Yan is lecturer at the China Women's University, Beijing.

I Meng Quan is lecturer at the Capital University of Economics and Business, School of Labour Economics.

Manuscript received on 23 October 2018. Accepted on 18 February 2019.

CHANG, Kai, and William BROWN. 2013. "The Transition From Individual to Collective Labour Relations in China." Industrial Relations Journal 44(2): 102-21.

CHEN, Feng. 2003. "Between the State and Labour: the Conflict of Chinese Trade Unions' Double Identity in Market Reforms." The China Quarterly 176(December): 1006-28.

CHEN, Feng. 2007. "Individual Rights and Collective Rights: Labour's Predicament in China." Communist and Post-Communist Studies 40(1): 59-79.

CHEN, Feng. 2010. "Trade Unions and the Quadripartite Interactions in Strike Settlement in China." The China Quarterly 201(March): 104-24

China Labour Bulletin. 2012. A Decade of Change - The Workers'Movement in China 2000-2010. http://www.clb.org.hk (accessed on 28 May 2018). 
CLARKE, Simon, Chang-Hee LEE, and Qi LI. 2004. "Collective Consultation and Industrial Relations in China." British Journal of Industrial Relations 42(2): 235-54.

DING, Daniel, Ge LAN, and Malcolm WARNER. 2001. "A New Form of Chinese Human Resource Management? Personnel and Labour-Management Relations in Chinese Township and Village Enterprises: A Case-Study Approach." Industrial Relations Journal 32: 328-43.

FRIEDMAN, Eli. 2014. Insurgency Trap: Labour Politics in post-Socialist China. Ithaca, New York: Cornell University Press.

FRIEDMAN, Eli, and Sarosh KURUVILLA. 2015. "Experimentation and Decentralization in Chinese Industrial Relations." Human Relations 68(2): 181-95.

FROISSART, Chloé. 2011. "La radicalisation des actions collectives en Chine et ses conséquences politiques" (The radicalisation of collective actions in China and its political consequences). Chronique Internationale de l'IRES 128: $15-24$.

FROISSART, Chloé. 2013. "Pour un salaire juste. L'évolution des revendications ouvrières en Chine" (Towards fair wages. The evolution of workers' demands in China). In Émilie Frenkiel and Jean-Louis Rocca (eds.), La Chine en mouvements (China in Motion). Paris: Presses universitaires de France. 43-58.

FROISSART, Chloé. 2014a. "L'émergence de négotiations collectives autonomes en Chine" (The emergence of autonomous collective bargaining in China). Critique internationale 65: 43-63.

FROISSART, Chloé. 2014b. "Using the Law as a 'Harmonious Weapon': The Ambiguities of Legal Activism in Favour of Migrant Workers in China." Journal of Civil Society 10(3): 255-72.

FROISSART, Chloé. 2015. "L'évolution de la dynamique des grèves en Chine et leur impact sur la démocratisation au sein des entreprises" (The evolution of strike dynamics in China and their impact on democratisation within enterprises). In Clément Sehier and Richard Sobel (eds.), Travail, luttes sociales et régulation du capitalisme dans la Chine contemporaine (Labour, social conflicts and regulation of capitalism in contemporary China). Lille: Presses Universitaires du Septentrion. 103-21.

FROISSART, Chloé. 2018. "Negotiating Authoritarianism and its Limits: Worker-led Collective Bargaining in Guandong Province." China Information 32(1): 23-45.

GALLAGHER, Mary E. 2014. "China's Workers Movement and the End of the Rapid-growth Era." Daedalus 143(2): 81-95.

GALLAGHER, Mary E. 2017. Authoritarian Legality in China: Law, Workers, and the State. New York: Cambridge University Press.

HOWELL, Jude. 2008. "All-China Federation of Trade Unions beyond Reform? The Slow March of Direct Elections." The China Quarterly 196(December): 845-63.

HOWELL, Jude. 2015. "Shall We Dance? Welfarist Incorporation and the Politics of State-Labour NGO Relations." The China Quarterly 223(September): 702-23.
HOWELL Jude, and Tim PRINGLE. 2018. "Shades of Authoritarianism and State-Labour Relations in China." British Journal of Industrial Relations 57(2): 247-74.

HUI, Elaine Sio-ieng, and Chris King-chi CHAN. 2015. "Beyond the UnionCentred Approach: Critical Evaluation of Recent Trade Unions Elections in China." British Journal of Industrial Relations 53(3): 601-27.

KURUVILLA, Sarosh, and Hao ZHANG. 2016. "Labour Unrest and Incipient Collective Bargaining in China." Management and Organization Review 12(1): 159-87.

LEE, Chiang-Hee, William BROWN, and Xiaoyi WEN. 2016. "What Sort of Collective Bargaining is Emerging in China?" British Journal of Industrial Relations 54(1): 214-36.

LEE, Ching Kwan, and Yonghong ZHANG. 2013. "The Power of Instability: Unraveling the Microfoundations of Bargained Authoritarianism in China." American Journal of Sociology 118(6): 1475-508.

MENG, Quan 孟泉. 2012. “谈判游戏中的“说和人': 以DLDA区为例” (Tanpan youxi zhong de "shuoheren":Yi DLDA qu wei li, The "mediator" in the negotiating game:The case of DLDA). 清华社会学评论 (Qinghua Shehuixue Pinglun) 6: 206-22.

PRINGLE, Tim. 2011. Trade Unions in China: The Challenge of Labour Unrest. New York: Routledge.

PRINGLE, Tim, and Quan MENG. 2018. "Taming Labour:Workers' Struggles, Workplace Unionism and Collective Bargaining on a Chinese Waterfront." ILR Review. DOI: 10.1177/0019793918768791.

TAYLOR, Bill, and Qi LI. 2007. "Is ACFTU a Union and Does it Matter?" Journal of Industrial Relations 49: 701-15.

WEN, Xiaoyi, and Kevin LIN. 2015. "Restructuring China's State Corporatist Industrial Relations System: The Wenling Experience." Journal of Contemporary China 24(94): 665-83.

UNGER, Jonathan, and Anita CHAN. 1995. "China, Corporatism, and the East Asian Model." The Australian Journal of Chinese Affairs 33: 29-53.

WU, Yatong 武雅粀, and WANG Jing 王晶. 2017. “企业工会改革的可能性 与局限性 - 基于组织有效性与合法性关系的考察” (Qiye gonghui gaige de kenengxing yu juxianxing - jiyu zuzhi youxiaoxing yu hefaxing guanxi de kaocha, Possibilities and limits of corporate unions: An analysis based on the relationship between effectiveness and legitimacy). 中国人力资源开 发 (Zhongguo renli ziyuan kaifa) 7: 36-46.

YANG, Tao 杨涛. 2018. “内生性选举: 珠三角地区基层工会选举的民主实践 探索” (Neishengxing xuanju: Zhusanjiao diqu jiceng gonghui xuanju de minzhu shijian tansuo, Endogenous elections: Exploration of democratic practices in grassroots union elections in the Pearl River Delta). Paper given at the first conference on Industrial problems and labour - Experiments and exploration of union reforms, Tsinghua University, 13 January 2018.

ZHU, Xiaoyin, and Anita CHAN. 2005. "Staff and Workers' Representative Congress, an Institutionalised Channel for the Expression of Employees' Interests?" Chinese Sociology and Anthropology 37(4): 6-33. 